\title{
An Analysis of Hong Kong Export Performance*
}

\author{
Yin-Wong Cheung \\ Economics Department, University of California, Santa Cruz, CA95064, USA
}

\begin{abstract}
$\underline{\text { Abstract }}$
The article examines the Hong Kong export performance. A standard export demand formulation is used as the benchmark. Then, we investigate the effects of real exchange rate volatility, "third" country competition, domestic wages, and costs of imports from China on export volume. The study models the Hong Kong domestic exports and re-exports separately, compares the performance of exports to the rest of the world, US and Japan, and uses destination-and-export-type specific unit value indexes to construct real exchange rates. It is found that Hong Kong export performance varies across export types and across destinations. In general, Hong Kong exports display mean-reverting dynamics, are positively influenced by foreign income, and are adversely affected by high value of its currency. The lagged export variable, foreign income, and real exchange rate provide most of the explanatory power. The other variables contribute only marginally in explaining the variability of Hong Kong exports.
\end{abstract}

JEL: F14

Running Head: Hong Kong Export Performance

* The author is grateful to Ken Chan, Micheal Devereux, Jiming Ha, Wensheng Peng, Matthew Yiu, an associate editor, and an anonymous referee for their helpful comments and suggestions. This paper was completed when the author was a research fellow at the Hong Kong Institute for Monetary Research, and he thanks the Institute for its hospitality. Desmond Hou provided excellent research assistance. The views expressed in this paper are those of the author and do not necessarily reflect those of the Hong Kong Institute for Monetary Research, its Council of Advisors, or Board of Directors.

Address for Correspondence: Economics Department, SS1, University of California, Santa Cruz, CA 95064, U.S.A. Email - cheung@,cats.ucsc.edu. Phone: (831) 459-5900 (fax); (831) 459-4247 (office). 


\section{Introduction}

The objective of this article is to study the behavior of Hong Kong exports. There is a long tradition in international economics to model trade flows. The usual focus is on income and price elasticities and their implications for trade balances and shock propagation mechanisms across economies. Most of the published empirical studies are based on trade data from developed countries (Goldstein and Khan, 1985; Hooper, Johnson and Marquez, 2000). ${ }^{1}$ Since Hong Kong is a small open economy, the study of its exports offers some alternative evidence on modeling trade flows.

In a typical trade model, the assumptions of a small open economy and perfect competition yield some clear and direct predictions about trade flows. These predictions, however, may not be relevant for trade data from the G7 and other industrial countries because of their size and the presence of implicit and explicit trade barriers. Hong Kong presents a different scenario. Hong Kong is a small open economy that is renowned for its laissez-faire policy and economic freedom (O’Driscoll et al., 2001). There may not be an economy in the world that perfectly meets the academic description of a small open economy with perfect competition. However, Hong Kong is arguably one of the few economies that has attributes very close these ideal conditions. Thus Hong Kong offers a good setting to exploit the small country assumption in studying trade flows.

1 Interested readers are referred to Goldstein and Khan (1985) and Hooper, Johnson and Marquez (2000) for a detailed discussion of issues and references related to trade equation modeling. 
The current empirical exercise uses a standard export demand equation as the benchmark. Then, we investigate the effects of real exchange rate volatility, "third" country competition, domestic wages, and costs of China imports on Hong Kong export volume. The study has several salient features. First, to alleviate the simultaneity and nonstationarity problems, the cointegration approach and the related error-correction specification are employed to examine the interactions between exports, foreign income, and export prices. The cointegration framework offers a convenient means to study the long-run and short-run interactions between these variables.

Second, Hong Kong domestic exports and re-exports are modeled separately. Hong Kong is an important entrepôt. Its export activity increasingly depends on re-exporting goods and services originated from China. A preliminary examination of data on domestic exports and re-exports suggests that these two export categories evolve quite differently over time. Thus, studying these two export types individually should give reliable measures of income and price elasticities. ${ }^{2}$ To highlight the variations across export destinations, we also compare the performance of Hong Kong aggregate exports, and its exports to the US and Japan.

Third, it is observed that the general price level, which is routinely used to construct the relative price variable in trade equations, does not correctly reflect the competitiveness of Hong Kong exports. In most part of the 1990s, the domestic inflation in Hong Kong was higher than that in the US. Since the Hong Kong dollar is effectively pegged to the US dollar, people usually assert that the Hong Kong dollar was overvalued before the 1997 financial

2 Chinn (2002), in studying aggregate US trade, reports a stable import demand function is obtained only after excluding computers and parts. 
crisis, and exports were adversely affected by the strong Hong Kong dollar. The claim on the effects of domestic inflation on Hong Kong exports, nonetheless, is over-stated. ${ }^{3}$ In fact, during this period, the export prices showed a declining trend and the Hong Kong export performance did not appear weakened. Thus, the use of a general price level index such as the consumer price index may not yield a proper assessment of Hong Kong export performance. In the current exercise, the relative price variables are the real exchange rates constructed from destination-and-export-type specific unit value indexes.

As anticipated, Hong Kong exports are found to behave differently across export types and across destinations. In general, Hong Kong exports display mean-reverting dynamics, are positively influenced by foreign income, and are adversely affected by the strength of its currency. The effects of real exchange rate volatility, "third" country competition, domestic wages, and the cost of imports from China on export volume depend on the category of exports under examining. In general, the effects on aggregate exports are different from those on exports to Japan and the US.

3 During the 1990s, Hong Kong experienced a high inflation rate that was closely related to the boom in the real estate market and other nontradables sectors. Apparently, the nontradables driven domestic inflation rate has a limited impact on export prices. The disconnect between prices of nontradables and exports contributes to the divergence of the Hong Kong CPI based and UVI based real exchange rates. The divergence of price indexes may explain why the conventional PPP for Hong Kong does not hold. Hawkins and Yiu (1995), for instance, observe that the Hong Kong real effective exchange rate based on export UVI was not appreciating during the early 1990s. 
Hong Kong is a very open economy. The ratio of trade (imports plus exports) to gross domestic product (GDP) is usually larger than 2. For instance, in 2001, the ratio of trade to GDP is pegged at 2.825 , the exports to GDP ratio is 1.439 , and the imports to GDP ratio is 1.386. It is widely conceived that exports contribute significantly to Hong Kong's economic success. Thus, it is conducive to investigate which is the key variable that determines Hong Kong exports. Among the factors that are statistically significant, it is found that a large portion of variations in Hong Kong exports is explained by their own past movements. The other variables contribute only marginally in explaining the variability of Hong Kong exports.

In the next section, we layout the basic analytical framework and discuss the choices of variables. Section three reports the results of estimating the benchmark export demand equations. The effects of real exchange rate volatility, "third" country competition, domestic wages, and the cost of China imports are investigated in Section four. Section four also presents a heuristic assessment of relative contributions of the explanatory variables. Section five contains some concluding remarks.

\section{The Framework}

In this study, the basic export demand function is given by the canonical specification

$$
y_{t}=f\left(x_{t}, r_{t}\right)
$$

where $y_{t}$ is the quantity of Hong Kong exports demanded by a foreign country, $x_{t}$ is the foreign country's real income, and $r_{t}$ is the relative price of exports given by Hong Kong real exchange rate. It is expected that the foreign income boosts demand for Hong Kong exports and a strong Hong Kong dollar discourages its exports. The single equation approach is considered to be "the major thrust of this literature" (Goldstein and Khan, 1985; p. 1097). 
There are some assumptions underlying the single equation approach. For instance, it is implicitly assumed that there is no money illusion and the exports are not inferior goods. Further, under the assumptions of market perfection and a small exporter who has no market power, the quantity of exports is determined by demand factors including foreign income and relative prices (Goldstein and Khan, 1985; Hooper and Kohlhagen, 1978). Apparently, the single equation approach is more appropriate for a small open economy such as Hong Kong, which has limited market power, than those industrial countries commonly examined in the empirical literature.

Next, we consider the choice of the dependent variable. Figure 1 depicts the Hong Kong aggregate domestic exports and aggregate re-exports. The aggregate total exports are given by the sum of domestic exports and re-exports. The sample is from 1991 to 2001, which is mainly dictated by availability of the monthly data examined in the following sections. The graph strongly suggests that the behavior of domestic exports is quite different from reexports. Specifically, domestic exports were declining while re-exports had a noticeable growth in the 1990s. A similar "divergent" behavior is also observed for domestic exports and re-exports to the US and Japan, the two countries that are examined in the following sections. Further, exports to different destinations (i.e. aggregate, Japan, and the US) behaved quite differently in the 1990s. Given their different time profiles, we study these different categories of export data separately.

Since export behavior can vary substantially across export types and destinations, a natural question to ask is whether the competitiveness of different categories of Hong Kong exports can be appropriately measured by the real exchange rate constructed from Hong Kong's general price level. The answer to this question appears to be negative. Figure 2 plots 
the Hong Kong real effective exchange rates constructed from the Hong Kong consumer price index (CPI), domestic export unit value index (UVI), re-export UVI, and total export UVI.

The Hong Kong real effective exchange rate based on CPI and those based on UVI's move in different directions for a good part of the 1990s. Specifically, the CPI based real effective exchange rate indicates that the Hong Kong dollar was appreciating from 1991 to 1998 and depreciating afterwards. In fact, some seriously concerns were raised about the appreciation of the CPI based real effective exchange rate and its implied burdens on Hong Kong exports in the 1990s. The three UVI based real effective exchange rates, on the other hand, present a very different scenario. The relative prices of Hong Kong exports were declining, instead of increasing as indicated by the CPI real effective exchange rate, throughout the 1990s. ${ }^{4}$

The contrasting behavior of CPI and UVI based real exchange rates indicates that the former real exchange rate may not accurately reflect the competitiveness of different categories of Hong Kong exports during our sample period. Thus, the export-type-anddestination specific UVI based real exchange rates, instead of the general CPI based real exchange rate, are used as the measure of the relative price in our export demand equation.

Given the above considerations, the variables in the export demand function are modified to $y_{i, j, t}, x_{j, t}$, and $r_{i, j, t}$. The exports and real exchange rates are both export type and destination specific. The i-subscript indicates the export type and $\mathrm{i}=$ domestic exports, reexports, and total exports. The export destinations are indexed by the $\mathrm{j}$-subscript and $\mathrm{j}=$

4. Cheung (2003) shows that there is a similar divergence between the CPI and UVI based Hong Kong real exchange rates against the US and Japan. 
aggregate, Japan, and the US. The foreign real income variables are destination specific and are given by the world, Japan, and US industrial production indexes.

\section{The Basic Export Demand Equation}

The basic export demand equation is examined using data on Hong Kong aggregate exports and Hong Kong exports to Japan and the US. The data on exports, foreign income, and real exchange rates are in logarithmic terms. Monthly data from 1991 to 2001 are considered. ${ }^{5}$ The augmented Dickey-Fuller and Johansen tests are used to examine the unit root and cointegration properties of $y_{i, j, t}, x_{j, t}$, and $r_{i, j, t}$. Since the augmented Dickey-Fuller test and the Johansen test are standard procedures, they are not discussed in the text to conserve space. Table 1 presents the augmented Dickey-Fuller unit root test results. The lag parameter is determined by the Akaike information criterion and is chosen to eliminate serial correlation in the residuals. For all the series under examination, the augmented Dickey-Fuller test does not reject the unit root null hypothesis. However, the unit root hypothesis is rejected by the first difference data. The results are largely consistent with those reported in the literature - a unit root process provides an adequate description for these economic variables.

Since the variables are I(1), the Johansen cointegration test procedure is used to determine the empirical long-run relationship between exports, foreign income, and real exchange rates. Again, the lag parameter used in the Johansen test is determined by the Akaike information criterion and is chosen to eliminate the serial correlation in the residuals.

5 A detailed description of these trade data and other data series used in the exercise is provided in Cheung (2003). 
The cointegration test results are given in Table 2. There is evidence of cointegration in seven of the nine trivariate systems under consideration. Two cointegrating relationships are found in four of these seven cases. In general, Hong Kong exports have an empirical long-run relationship with the corresponding foreign income and real exchange rate. The long-run income and price elasticities are inferred from the estimated cointegrating vectors.

For aggregate re-exports and aggregate total exports, the long-run income elasticity estimates are between 0.6 to 0.8 . Four country-specific cases have two cointegrating vectors. The obvious issue is which one of the cointegrating vectors gives the relevant information. We use the significance the error correction term in the subsequent error correction estimation to select the relevant cointegrating vector. It turns out that only the domestic exports to the US equation has two significant error correction terms. For this case, the price variable has the correct sign in the first cointegrating vector and the income variable has the correct sign in the second vector. The other three cases have one significant error term corresponding to the first cointegrating vector given in the table. Thus, the income elasticity estimates are in the ranges of 2.2 to 2.7 for Japan and 0.0 to 3.4 for the US. These estimates display a level of variability higher than those found among the developed countries. For instance, Goldstein and Khan (1985) assess that the income elasticity is between 1 and 2. Hooper, Johnson and Marquez (2000) find the income elasticities for the G-7 countries are between 0.8 and 1.6.

Using the same approach to select the cointegrating vectors, the long-run price elasticity estimates are in the range of 0.4 to 0.7 for the aggregate exports, 2.7 to 2.8 for exports to Japan, and 2.2 to 3.6 for exports to the US. The result is consistent with the consensus that the estimated aggregate price elasticities are smaller than the country-specific elasticity estimates. The argument for smaller aggregate price elasticity estimates is that, in 
aggregate trade equations, goods with relatively low price elasticities tend to have the largest price variation and a dominant effect on price elasticity estimates (Orcutt, 1950). Again these estimates appear to be more variable than those reported in Goldstein and Khan (1985) and Hooper, Johnson and Marquez (2000).

In the majority cases, the elasticity estimates have the correct sign. Nonetheless, these estimates exhibit considerable variations across different types of exports and export destinations. Both the income and price elasticities of exports to Japan are larger than those of aggregate exports. On the other hand, the price elasticities of exports to the US tend to be larger than those of aggregate exports while the US income elasticities are smaller. The result highlights the heterogeneity of export behavior and the relevancy of examining these different export categories separately.

The dynamic interaction between exports, foreign income, and real exchange rates are examined using the following equation:

$$
\mathrm{Y}_{\mathrm{i}, \mathrm{j}, \mathrm{t}}=\alpha+\sum_{\mathrm{k}=1}^{\mathrm{n}} \alpha_{\mathrm{i}, \mathrm{j}, \mathrm{k}} \mathrm{Y}_{\mathrm{i}, \mathrm{j}, \mathrm{t}-\mathrm{k}}+\sum_{\mathrm{k}=1}^{\mathrm{m}} \beta_{\mathrm{i}, \mathrm{j}, \mathrm{k}} \mathrm{X}_{\mathrm{j}, \mathrm{t}-\mathrm{k}}+\sum_{\mathrm{k}=1}^{\mathrm{p}} \gamma_{\mathrm{i}, \mathrm{j}, \mathrm{k}} \mathrm{R}_{\mathrm{i}, \mathrm{j}, \mathrm{t}-\mathrm{k}}+\theta_{\mathrm{ijj}} \mathrm{E}_{\mathrm{i}, \mathrm{j}, \mathrm{t}-1}+\varepsilon_{\mathrm{i}, \mathrm{j}, \mathrm{t}},
$$

where $\mathrm{Y}_{\mathrm{i}, \mathrm{j}, \mathrm{t}}, \mathrm{X}_{\mathrm{j}, \mathrm{t}}$, and $\mathrm{R}_{\mathrm{i}, \mathrm{j}, \mathrm{t}}$ are, respectively, the first differences of $y_{i, j, t}, x_{j, t}$, and $r_{i, j, t}$. $\mathrm{E}_{\mathrm{i}, \mathrm{j}, \mathrm{t}-\mathrm{i}}$ is the error correction term derived from the cointegrating vector and is included in the equation in which the variables are cointegrated. $\boldsymbol{E}_{\mathrm{i}, \mathrm{j}, \mathrm{t}}$ is an error term. Under equation (2), which is known as the error correction specification, exports adjust to their past history, shortrun variations in foreign income and real exchange rates, and deviations from the (empirical) long-run equilibrium represented by the error correction term. Compared with previous studies that use either the data themselves or their first differences, equation (2) appropriately accounts for the I(1) properties and the long-run and short-run interactions between exports, foreign income, and real exchange rates. 
Table 3a contains estimation results from aggregate exports and Table $3 \mathrm{~b}$ contains those from exports to Japan and the US. To conserve space, only significant coefficient estimates are presented. The robust t-statistics are reported in parentheses underneath coefficient estimates. The $\alpha_{\mathrm{i}, \mathrm{j}, \mathrm{k}}$ coefficients are all negative; indicating exports have "mean reverting" behavior. The lag length ranges from two to nine months.

The short-run effect of foreign income is captured by $\beta_{\mathrm{i}, \mathrm{j}, \mathrm{k}}$. According to the coefficient estimates, the income effect is positive in all the specifications - an increase in foreign income boosts demand for Hong Kong exports. The lag structure is quite diverse and ranges from three lags for the three types of exports to Japan to eight lags for domestic exports to the US. The multiplier effect given by $\sum_{\mathrm{k}=1}^{\mathrm{m}} \beta_{\mathrm{i}, \mathrm{j}, \mathrm{k}} /\left(1+\sum_{\mathrm{k}=1}^{\mathrm{n}} \alpha_{\mathrm{i}, \mathrm{j}, \mathrm{k}}\right)$ depends on the export category. Exports to the US have the largest multiplier effect ( 3.1 for total exports to 4.2 for domestic exports) followed by aggregate exports (1.4 for re-exports to 2.0 for domestic exports) and exports to Japan ( 0.3 for total exports to 0.6 for domestic exports).

The short-run price effect is surprisingly weak. The $\gamma_{\mathrm{i}, \mathrm{j}, \mathrm{k}}$ coefficient is significant in only two cases: domestic exports to Japan and re-exports to the US. The two significant $\gamma_{\mathrm{i}, \mathrm{j}, \mathrm{k}}$ coefficients have the expected sign (an increase in $\mathrm{R}_{\mathrm{i}, \mathrm{j}, \mathrm{t}}$ means a real depreciation of the Hong Kong dollar). Is the Hong Kong linked-exchange-rate-system responsible for the weak shortrun price effect? The linked exchange rate system effectively pegs the Hong Kong dollar to the US dollar and, hence, reduces the variability of the real exchange rate between Hong Kong and US and mitigates the price effect on exports to the US. However, the Hong Kong dollar real exchange rates against other currencies still experience substantial variation during the sample. The linked exchange rate system, thus, does not provide a good explanation why 
the $\gamma_{\mathrm{i}, \mathrm{j}, \mathrm{k}}$ coefficient is insignificant in the aggregate exports equations and the two exports to Japan equations.

The error correction term has the expected negative sign in each of the cointegrated cases. At the first glance, the $\theta$ estimates are quite large for monthly data. Without taking the lag structure of $\mathrm{Y}_{\mathrm{i}, \mathrm{j}, \mathrm{t}}$ into consideration, the $\theta$ estimates imply a monthly reversion speed of up to $27 \%$ of deviation from equilibrium. However, when we incorporate the lag structure of $\mathrm{Y}_{\mathrm{i}, \mathrm{j}, \mathrm{t}}$ and consider $\theta_{\mathrm{i}, \mathrm{j}} /\left(1+\sum_{\mathrm{k}=1}^{\mathrm{n}} \alpha_{\mathrm{i}, \mathrm{j}, \mathrm{k}}\right)$, the reversion rate is reduced to a level of $7 \%$ or less per month for six cases. The adjusted reversion rates for the remaining two cases are $13 \%$ for domestic exports to the US and $15 \%$ for aggregate domestic exports.

The results in Tables $3 \mathrm{a}$ and $3 \mathrm{~b}$ show that individual coefficient estimates and lag structure patterns vary considerably across different export categories. Given the dominance of re-exports, the specifications of total exports and re-exports equations share some similarities. The Q-statistics indicate that the estimated residuals in all the specifications in Table 3 are free of serial correlation. ${ }^{6}$ These specifications have a good explanatory power. The adjusted $\mathrm{R}^{2}$ statistics are in the range of 0.37 to 0.55 . For each export type, the aggregate export equation garners the highest adjusted $\mathrm{R}^{2}$ statistics. Overall, the error correction model (2) explains the Hong Kong export data pretty well.

\section{Additional Analyses}

6 The LM diagnostic test offers similar conclusions. 
Besides income and price, there are other factors affecting export behavior. In this section, we consider the effect of real exchange rate volatility, the "third" country effect, Hong Kong wage rates, and the cost of imports from China on Hong Kong exports.

The implication of real exchange rate volatility for trade has been a hotly contested issue since the breakdown of the Bretton-Wood system. The recent Asian financial crisis revives the discussion on the choice of exchange rate regimes and its implications for exchange rate volatility and trade. Interestingly, both the theoretical and empirical studies do not offer a firm conclusion on the effect of real exchange rate volatility on international trade (Côté, 1994). The "third" country effect is motivated by the observation that Hong Kong exports compete with both domestic producers in the importing country and other countries exporting to the same importing country. Thus the (relative) prices at which the other countries export to the same importing country also affect Hong Kong exports. The wage and China variables are included to examine the effects of domestic wages and costs of importing from China on Hong Kong exports.

The effects of these four additional variables are examined using the augmented export demand specification

$$
\begin{aligned}
\mathrm{Y}_{\mathrm{i}, \mathrm{t}, \mathrm{t}}= & \alpha+\sum_{\mathrm{k}=1}^{\mathrm{n}} \alpha_{\mathrm{i}, \mathrm{j}, \mathrm{k}} \mathrm{Y}_{\mathrm{i}, \mathrm{j}, \mathrm{t}-\mathrm{k}}+\sum_{\mathrm{k}=1}^{\mathrm{m}} \beta_{\mathrm{i}, \mathrm{j}, \mathrm{K}} \mathrm{X}_{\mathrm{j}, t-\mathrm{k}}+\sum_{\mathrm{k}=1}^{\mathrm{p}} \gamma_{\mathrm{i}, \mathrm{j}, \mathrm{k}} \mathrm{R}_{\mathrm{i}, \mathrm{j}, \mathrm{t}-\mathrm{k}}+\theta_{\mathrm{ij}} \mathrm{E}_{\mathrm{i}, \mathrm{j}, \mathrm{t}-1}+ \\
& \sum_{\mathrm{k}=0}^{\mathrm{q}} \delta_{\mathrm{i}, \mathrm{j}, \mathrm{k}} \mathrm{V}_{\mathrm{i}, \mathrm{j}, \mathrm{t}-\mathrm{k}}+\sum_{\mathrm{k}=1}^{\mathrm{s}} \gamma_{\mathrm{i}, \mathrm{j}, \mathrm{k}}^{*} \mathrm{R}_{\mathrm{i}, \mathrm{j}, \mathrm{t}-\mathrm{k}}^{*}+\sum_{\mathrm{k}=1}^{\mathrm{r}} \lambda_{\mathrm{k}} \mathrm{W}_{\mathrm{t}-\mathrm{k}}+\sum_{\mathrm{k}=1}^{\mathrm{u}} \tau_{\mathrm{i}, \mathrm{j}, \mathrm{k}} \mathrm{CN}_{\mathrm{i}, \mathrm{j}, \mathrm{t}-\mathrm{k}}+\varepsilon_{\mathrm{i}, \mathrm{j}, \mathrm{t}} .
\end{aligned}
$$

The real exchange rate volatility effect is captured by $\mathrm{V}_{\mathrm{i}, \mathrm{j}, \mathrm{t}}$, which is the conditional volatility of $\mathrm{R}_{\mathrm{i}, \mathrm{j}, \mathrm{t}}$. Specifically, a $\operatorname{GARCH}(\mathrm{p}, \mathrm{q})$ model is fitted to each individual real exchange rate series and the resulting conditional variance estimate is used as a proxy for real exchange rate 
volatility. West, Edison and Cho (1993) offer a justification for the use of GARCH estimates to measure exchange rate volatility. ${ }^{7}$

The "third" country price effect is represented by the variable $\mathrm{R}_{\mathrm{i}, \mathrm{j}, \mathrm{k}}^{*}$. It is based on the Hong Kong export UVI and the destination economy's overall import UVI. For example, when $i=$ re-exports and $j=$ Japan, $R_{i, j, k}^{*}$ is defined as the first log difference of HKJY*(JPMP/UVI_RYJP), where HKJY is the Hong Kong dollar Japanese yen exchange rate, JPMP is the UVI of Japanese imports, and UVI_RYJP is the UVI of Hong Kong reexports to Japan. A positive $\mathrm{R}_{\mathrm{i}, \mathrm{j}, \mathrm{k}}^{*}$ means an improved competitiveness of Hong Kong exports.

The first log difference of the real payroll index for manufacturing sector, $\mathrm{W}_{\mathrm{t}}$, is the proxy for domestic wage/factor effects. Since we do not have the breakdown of imports from China according to our export market classification, we use an overall UVI, albeit an imprecise measure, to evaluate the China cost effect. The variable we considered is the ratio of the UVI of Hong Kong imports from China to the UVI of Hong Kong exports to the respective destination. Essentially, we implicitly postulate that Hong Kong export activity is affected by the cost of importing from China relative to the Hong Kong export price. Thus, the China cost factor $\mathrm{CN}_{\mathrm{i}, \mathrm{j}, \mathrm{t}}$ is given by the first log difference of the UVI of Hong Kong imports from China relative to the type-and-destination-specific Hong Kong export UVI.

The results from estimating (3) are reported in Table 4. Again, only significant coefficient estimates and their robust t-statistics are presented. The effects of these four

7 The GARCH(p,q) specifications used to generate the $\mathrm{V}_{\mathrm{i}, \mathrm{j}, \mathrm{t}}$ series and some diagnostics of these specifications are given in Cheung(2003). 
additional explanatory variables are discussed in order. First, does real exchange rate volatility deter or promote trade? The answer, in this case, depends on which export series is being considered. For the three aggregate export equations, $\mathrm{V}_{\mathrm{i}, \mathrm{j}, \mathrm{t}}$ is significantly negative at the first lag. Real exchange rate volatility deters aggregate exports from Hong Kong. On the other hand, real exchange rate volatility has a positive impact on some types of exports to Japan and the US. In the literature there are theoretical arguments and empirical evidence for both a positive and negative real exchange rate volatility effect. In this exercise, the intrigue observation is the different impacts of real exchange rate volatility on exports from the same economy to different destinations. While real exchange rate volatility promotes Hong Kong exports to her two trading partners; namely Japan and the US, it hinders her aggregate exports. Further, the lag structure is quite different across destinations - one lag for the aggregate export equations and 2 to 8 lags for exports to Japan and the US.

As expounded in the literature real exchange rate volatility is one form of risks faced by exporters, its effect on the volume of exports depends on its interaction with other factors affecting export behavior. Additional information, including the mix of exports, is required to explain the heterogeneous volatility effects. Unfortunately, we do not have the necessary information to investigate the phenomenon.

The results in Table 4 show that the $\gamma_{\mathrm{i}, \mathrm{j}, \mathrm{k}}^{*}$ estimates are negative for aggregate exports but are positive for some types of exports to Japan. Given the definition of $\mathrm{R}_{\mathrm{i}, \mathrm{j}, \mathrm{k}}^{*}$, we expect $\gamma_{\mathrm{i}, \mathrm{j}, \mathrm{k}}^{*}$ to be positive. Thus, the results for exports to Japan and the US are consistent with the "third" country competition argument. The results from aggregate export data are, however, 
quite puzzling. The negative coefficients in the aggregate export equations may be partially explained by the following two reasons. First, it is noted that the $\gamma_{\mathrm{i}, \mathrm{j}, \mathrm{k}}^{*}$ estimates in the aggregate export equations are only marginally significant according to the robust t-statistics. They are included mainly because they marginally improve the adjusted $\mathrm{R}^{2}$. Another related issue is the definition of $\mathrm{R}_{\mathrm{i}, \mathrm{j}, \mathrm{k}}^{*}$. For aggregate exports, the world import UVI is used to construct the "third" country price effect variable. It is likely that the weights used to construct the world import UVI are different from those to construct the Hong Kong real effective exchange rate.

The effect of the wage factor $\left(\mathrm{W}_{\mathrm{t}}\right)$ varies across export destinations. An upsurge in the real payroll index discourages exports to Japan and the US. For aggregate exports, the real payroll effect is more complex. At the first lag, a high real payroll index tends to shrink aggregate exports. However, at the fifth lag, the real payroll effect is found to be positive. It is not sure what is the cause of the positive real payroll effect.

Hong Kong has close economic ties with the Mainland China. In addition to reexporting and outward-processing trade, Hong Kong relies on China for her daily necessities and some basic materials. It is instructive to investigate if the costs of importing from China have any implications for Hong Kong export performance. The estimation results show that the China factor captured by $\mathrm{CN}_{\mathrm{i}, \mathrm{j}, \mathrm{t}}$ has a discernable effect on aggregate exports. However, its influence on the country-specific exports is quite ambiguous. In Table $4 \mathrm{a}$, the $\mathrm{CN}_{\mathrm{i}, \mathrm{j}, \mathrm{t}}$ has a negative coefficient in the three aggregate export equations; indicating that a high cost of importing from China impedes Hong Kong export activity. The $\tau_{\mathrm{i}, \mathrm{j}, \mathrm{k}}$ coefficient is marginally significant for aggregate domestic exports but quite significant of the other two aggregate 
export types. The China cost effect on country-specific exports, on the other hand, only shows up in the equation of domestic exports to the US. Even though the sign is correct, the level of statistical significance is lower than the conventional $5 \%$ or $10 \%$ level. Thus, the China cost factor may have a more prominent effect on exports to destinations other than Japan and the US.

From Table 4, we find that the variables $\mathrm{V}_{\mathrm{i}, \mathrm{j}, \mathrm{t}}, \mathrm{R}_{\mathrm{i}, \mathrm{j}, \mathrm{t}}^{*}, \mathrm{~W}_{\mathrm{t}}$, and $\mathrm{CN}_{\mathrm{i}, \mathrm{j}, \mathrm{t}}$ affect Hong Kong export performance. All the specifications in Table 4 pass the residual correlation Qtest. Nonetheless, the evidence is mainly statistical in nature. Even though these variables are found to be statistically significant, their effects are not homogenous across export types and export destinations and some of the estimated effects are not completely consistent with theoretical predictions. Table 5 offers a heuristic assessment of the relative explanatory powers of various groups of right-hand-side variables.

In Table 5, we report the adjusted $\mathrm{R}^{2}$ statistics, which are proxies for explanatory power, from fitting individual groups of regressors. Two specifications are considered: the basic specification given by equation (2) and the augmented specification given by equation (3). For the case of equation (2), we calculate the individual explanatory powers of $\mathrm{Y}_{\mathrm{i}, \mathrm{j}, \mathrm{t}-\mathrm{k}}$, $\left(\mathrm{X}_{\mathrm{j}, \mathrm{t}-\mathrm{k}}, \mathrm{R}_{\mathrm{i}, \mathrm{j}, \mathrm{t}-\mathrm{k}}\right)$, and $\left(\mathrm{Y}_{\mathrm{i}, \mathrm{j}, \mathrm{t}-\mathrm{k}}, \mathrm{E}_{\mathrm{i}, \mathrm{j}, \mathrm{t}-\mathrm{l}}\right)$ and report the results in Panel A. One observation stands out - the lagged export variables provide most of the explanatory power. The non- $\mathrm{Y}_{\mathrm{i}, \mathrm{j}, \mathrm{t}-\mathrm{k}}$ variables explain very little about the variation in Hong Kong exports. Among the non- $\mathrm{Y}_{\mathrm{i}, \mathrm{j}, \mathrm{t}-\mathrm{k}}$ variables, the error correction term $\mathrm{E}_{\mathrm{i}, \mathrm{j}, \mathrm{t}-\mathrm{l}}$ offers the best incremental explanatory power in two cases - re-exports and total exports to Japan; it adds $16 \%$ to the adjusted $\mathrm{R}^{2}$. 
The case of equation (3) is considered in Panel B of Table 5. In this panel, we garner $\mathrm{V}_{\mathrm{i}, \mathrm{j}, \mathrm{t}-\mathrm{k}}, \mathrm{R}_{\mathrm{i}, \mathrm{j}, \mathrm{t}-\mathrm{k}}^{*}, \mathrm{~W}_{\mathrm{t}-\mathrm{k}}$, and $\mathrm{CN}_{\mathrm{i}, \mathrm{j}, \mathrm{t}-\mathrm{k}}$ into one group. The results suggested that these four variables as a group have limited ability in explaining Hong Kong export variability. Even though they are statistically significant in these export equations, their explanatory power, gauged by the adjusted $\mathrm{R}^{2}$, ranges from $0 \%$ to $9 \%$. The results in Panel B corroborate those in Panel A and indicate that the lagged export variables are the key variables explaining Hong Kong export variability.

The inference of the relative contributions of these groups of regressors is not likely to be spurious. For a given export equation, the sum of the adjusted $R^{2}$ statistics from individual regressor groups is less than the adjusted $\mathrm{R}^{2}$ statistic from the regression in which all these regressors are included. For example, consider equation (3) for the aggregate domestic exports. The results in Panel B show that the adjusted $\mathrm{R}^{2}$ statistics for the three components $\left(\mathrm{Y}_{\mathrm{i}, \mathrm{j}, \mathrm{t}-\mathrm{k}}, \mathrm{E}_{\mathrm{i}, \mathrm{j}, \mathrm{t}-1}\right), \mathrm{X}_{\mathrm{j}, \mathrm{t}-\mathrm{k}}$, and $\left(\mathrm{V}_{\mathrm{i}, \mathrm{j}, \mathrm{t}-\mathrm{k}}, \mathrm{R}_{\mathrm{i}, \mathrm{j}, \mathrm{t}-\mathrm{k}}^{*}, \mathrm{~W}_{\mathrm{t}-\mathrm{k}}, \mathrm{CN}_{\mathrm{i}, \mathrm{j}, \mathrm{t}-\mathrm{k}}\right)$ are, respectively, 39\%, 4\%, and 4\%. The sum of the three statistics is smaller than $59 \%$, which is the adjusted $\mathrm{R}^{2}$ statistic of the regression that includes all three groups of regressors. Thus, these regressors tend to complement each other in explaining the variability of exports and the individual adjusted $\mathrm{R}^{2}$ statistics do not over-state the explanatory power of individual regressor groups. Even allowing for the complementary effect, there is still strong evidence on the significant role played by lagged exports in explaining Hong Kong export performance.

\section{Concluding Remarks}

The paper examines the Hong Kong monthly export performance from 1991 to 2001. To address the simultaneity and nonstationarity problems, the cointegration framework and 
the related error-correction specification are employed to study the canonical relationship between exports, foreign income, and real exchange rates. The exercise is then extended to investigate the incremental explanatory power of real exchange rate volatility, "third" country competition, domestic wages, and costs of imports from China. The export data are categorized according to their types (domestic exports, re-exports, and the total) and destinations (the US, Japan, and the rest of the world) because the time paths of these export series are quite different during the sample period. Further, the destination-and-export-type specific unit value indexes are used to construct the relative prices in the export demand equations.

In sum the selected variables explain the Hong Kong exports quite well. Most of the significant variables have the expected sign. The adjusted $\mathrm{R}^{2}$ statistics, which measure the goodness-of-fit, of the Hong Kong export models are in the range of 0.38 (domestic exports to Japan) to 0.65 (total exports to the rest of the world). However, the effects of these economic factors on the volume of exports vary across types and destinations. One noticeable difference is found between aggregate exports and exports to Japan and the US. For instance, effects of real exchange rate volatility, "third" country competition, and domestic wages on aggregate exports are different from those on exports to Japan and the US. The use of aggregate export data can give a misleading picture if the focus is on the behavior of a specific category of exports.

It is known that the strength and the growth of the Hong Kong economy depend heavily on its export activity. Given its current economic difficulties, information on factors affecting Hong Kong export performance can provide some useful insights on formulating policies to improve the situation. Our analyses indicate that, far more than the external factors 
including foreign income, relative prices, real exchange rate volatility, and costs of importing from China, the lagged exports are the key factors determining Hong Kong exports. One interpretation is that the extraordinary export performance of Hong Kong in the past is likely driven by the internal dynamics of exports themselves rather than external demand conditions. Instead of waiting for external conditions to improve, a fruitful policy is to explore ways to increase the breadth and depth of the export market and, hence, set the exports on a new dynamic path. However, a limitation of the current exercise is that, given the models under investigation, it does not offer insights on exactly what policy should be pursued to explore and expand the export market. Further analyses evaluating effects of different types of export promoting policies are thus warranted. 


\section{References}

Côté, A. (1994) “Exchange Rate Volatility and Trade: A Survey,” Bank of Canada Working Paper 94-5.

Cheung, Y.-W. (2003) “An Analysis of Hong Kong Export Performance,” HKIMR Working Paper \#9/2003.

Cheung, Y.-W. and K. S. Lai (1995) “ Lag Order and Critical Values of the Augmented Dickey-Fuller Test," Journal of Business \& Economic Statistics 13, 277-280.

Cheung, Y.-W. and K. S. Lai (1993) “Finite-Sample Sizes of Johansen's Likelihood Ratio Tests for Cointegration," Oxford Bulletin of Economics and Statistics 55, 313-328.

Chinn, M. (2002) "Doomed to Deficits? Aggregate U.S. Trade Flows Re-examined," manuscript, University of California, Santa Cruz.

Goldstein, M. and M. S. Khan (1985) “Income and Price Effects in Foreign Trade,” Chapter 20 in R.W. Jones and P.B. Kenen eds., Handbook of International Economics, vol. II, 1041-1105. Elsevier Science Publishers B.V.

Hawkins, J. and M. Yiu. (1995) “Real and Effective Exchange Rates,” Hong Kong Monetary Authority Quarterly Bulletin 5, 136 - 147.

Hooper, P. and S. W. Kohlhagen (1978) “The Effect of Exchange Rate Uncertainty on the Prices and Volume of International Trade," Journal of International Economics 8, 483-511.

Hooper, P., K. Johnson and J. Marquez (2000) “Trade Elasticities for G-7 Countries,” Princeton Studies in International Economics No. 87. Princeton, NJ: Princeton University. 
O’Driscoll, G. P., K. R. Holmes, and M. Kirkpatrick, Eds. (2001) 2001 Index of Economic Freedom, Washington, D.C.: The Heritage Foundation and New York: Wall Street Journal.

Orcutt, G. (1950) “Measurement of Price Elasticities in International Trade,” Review of Economics and Statistics 32, 117-132.

West, K., H. J. Edison, and D.C. Cho (1993) “A Utility-Based Comparison of Some Models of Exchange Rate Volatility," Journal of International Economics 35, 23-45 
Table 1. Unit Root Test Results

\begin{tabular}{|c|c|c|c|c|c|c|}
\hline \multirow[b]{2}{*}{ Variables } & \multicolumn{3}{|c|}{ Levels } & \multicolumn{3}{|c|}{ First Differences } \\
\hline & ADF statistics (lag) & $Q(6)$ & $\mathbf{Q}(12)$ & ADF statistics (lag) & $Q(6)$ & $\mathbf{Q}(12)$ \\
\hline DYA & $-3.025(4)$ & $0.20(1.000)$ & $10.52(0.570)$ & $-8.365^{*}(3)$ & $1.01(0.985)$ & $11.02(0.528)$ \\
\hline RYA & $-1.998(11)$ & $0.59(0.997)$ & $5.07(0.955)$ & $-2.724^{\wedge}(7)$ & $0.86(0.990)$ & $15.49(0.216)$ \\
\hline TYA & $-2.043(11)$ & $0.58(0.997)$ & $5.18(0.952)$ & $-3.011 *(7)$ & $0.85(0.991)$ & $15.08(0.237)$ \\
\hline AIP & $-2.810(11)$ & $1.13(0.980)$ & $5.77(0.927)$ & $-3.146^{*}(10)$ & $1.23(0.975)$ & $5.49(0.940)$ \\
\hline RDYA & $-2.529(7)$ & $0.22(1.000)$ & $2.28(0.999)$ & $-3.712 *(6)$ & $0.25(1.000)$ & $3.55(0.990)$ \\
\hline RRYA & $-2.502(7)$ & $0.52(0.998)$ & $8.97(0.706)$ & $-3.632 *(6)$ & $0.46(0.998)$ & $9.85(0.629)$ \\
\hline RTYA & $-2.526(7)$ & $0.41(0.999)$ & $7.01(0.857)$ & $-3.615 *(6)$ & $0.43(0.999)$ & $8.14(0.774)$ \\
\hline DYJP & $-1.221(4)$ & $1.01(0.985)$ & $6.46(0.891)$ & $-7.940 *(3)$ & $1.11(0.981)$ & $6.74(0.874)$ \\
\hline RYJP & $-2.309(7)$ & $0.80(0.992)$ & $6.25(0.903)$ & $-3.965 *(5)$ & $2.07(0.913)$ & $3.93(0.985)$ \\
\hline TYJP & $-2.085(7)$ & $0.61(0.996)$ & $8.37(0.756)$ & $-3.930 *(5)$ & $2.34(0.886)$ & $7.36(0.833)$ \\
\hline JPIP & $-2.946(8)$ & $1.68(0.947)$ & $11.15(0.516)$ & $-2.574^{\wedge}(6)$ & $0.84(0.991)$ & $9.92(0.623)$ \\
\hline RDYJP & $-2.148(4)$ & $1.66(0.949)$ & $8.81(0.719)$ & $-6.412 *(3)$ & $2.05(0.916)$ & $8.91(0.711)$ \\
\hline RRYJP & $-1.854(5)$ & $1.99(0.921)$ & $10.51(0.571)$ & $-6.084 *(4)$ & $1.82(0.936)$ & $10.27(0.592)$ \\
\hline RTYJP & $-1.904(5)$ & $1.74(0.942)$ & $10.30(0.590)$ & $-6.059 *(4)$ & $1.59(0.953)$ & $10.09(0.608)$ \\
\hline DYUS & $-2.686(4)$ & $0.31(0.999)$ & $4.16(0.980)$ & $-14.603 *(1)$ & $3.34(0.766)$ & $8.04(0.782)$ \\
\hline RYUS & $-2.986(6)$ & $0.02(1.000)$ & $3.53(0.990)$ & $-9.651 *(2)$ & $2.29(0.891)$ & $7.60(0.815)$ \\
\hline TYUS & $-2.950(6)$ & $0.50(0.998)$ & $3.52(0.991)$ & $-10.397 *(2)$ & $2.19(0.901)$ & $5.40(0.943)$ \\
\hline USIP & $1.154(3)$ & $2.47(0.872)$ & $5.46(0.941)$ & $-4.159 *(2)$ & $2.48(0.870)$ & $7.05(0.854)$ \\
\hline RDYUS & $-1.143(2)$ & $4.93(0.553)$ & $9.59(0.652)$ & $-6.639 *(1)$ & $3.39(0.758)$ & $9.27(0.679)$ \\
\hline RRYUS & $-0.727(8)$ & $0.71(0.994)$ & $6.74(0.874)$ & $-2.881 *(7)$ & $0.59(0.997)$ & $6.45(0.892)$ \\
\hline RTYUS & $-0.793(8)$ & $0.20(1.000)$ & $6.61(0.882)$ & $-3.248 *(6)$ & $1.11(0.981)$ & $12.48(0.408)$ \\
\hline
\end{tabular}

Note: The significance of augmented Dickey-Fuller statistics at the $5 \%(10 \%)$ level is indicated by $*(\wedge)$ (Cheung and Lai, 1995). The level-specification contains a time trend and an intercept. The first-difference version allows for only an intercept. P-values are given in parentheses next to the $Q(p)$ statistics; $p=6,12$. The variables are grouped according to export destinations; namely aggregate exports, exports to Japan, and exports to the US. The variables related to the aggregate export regression are DYA = aggregate domestic exports, RYA = aggregate re-exports, TYA = aggregate total exports (domestic exports + re-exports), AIP = 'aggregate' industrial production given by the world industrial production index, RDYA $=$ real effective exchange rate (REER) based on aggregate domestic export unit value index $(\mathrm{UVI})$, RRDY $=$ REER based on aggregate re-export UVI, and RTYA = REER based on aggregate total export UVI. Variables related to exports to Japan and to the US regressions are similarly defined with the "A" for aggregate replaced by "JP" for Japan and "US" for the US. See Cheung (2003) for definitions of these variables. 
Table 2. Cointegration Test Results

\begin{tabular}{lllll}
\hline \multirow{5}{*}{ Aggregate } & Export Type & $(\boldsymbol{T}, \boldsymbol{k})$ & $\begin{array}{l}\text { Trace Statistics } \\
\mathrm{H}(0): r=(2,1,0)\end{array}$ & $\begin{array}{l}\text { CV(s) } \\
(\mathrm{y}, \mathrm{x}, \mathrm{r})\end{array}$ \\
\cline { 2 - 5 } & DY & $(121,6)$ & $(0.06,4.95,32.85)$ & $(1,1.736,-0.378)$ \\
& RY & $(121,6)$ & $\left(3.65,11.76,44.29^{*}\right)$ & $(1,-0.796,-0.681)$ \\
& TY & $(121,6)$ & $\left(3.24,10.94,39.41^{* *}\right)$ & $(1,-0.622,-0.661)$ \\
\cline { 2 - 5 } Japan & DY & $(124,4)$ & $(0.13,7.77,27.84)$ & $(1,22.742,14.829)$ \\
& RY & $(122,6)$ & $\left(4.70,24.35^{* *}, 47.93^{*}\right)$ & $\begin{array}{l}(1,-2.192,-2.784) \\
(1,-63.117,-13.327)\end{array}$ \\
& & & & $(1,-2.731,-2.706)$ \\
& TY & $(122,6)$ & $\left(4.76,24.15^{* *}, 47.79^{*}\right)$ & $(1,1.166,-2.211)$ \\
\cline { 2 - 5 } The U.S. & RY & $(127,1)$ & $\left(5.03,24.57^{*}, 51.79^{*}\right)$ & $(1,-0.147,1.978)$ \\
& DY & $(123,5)$ & $\left(5.03,19.15,52.03^{*}\right)$ & $(1,0.027,-3.615)$ \\
& TY & $(123,5)$ & $\left(8.20,23.19^{* *}, 55.61^{*}\right)$ & $\begin{array}{l}(1,0.035,-2.935) \\
(1,-3.382,0.295)\end{array}$ \\
\hline
\end{tabular}

Note: The Johansen cointegration test results for nine categories of Hong Kong exports and their corresponding income and price variables are reported. The export types are DY = domestic exports, $\mathrm{RY}=$ re-exports, and $\mathrm{TY}=$ total exports (domestic exports + re-exports). The effective sample size and lag parameter are given under the column labelled "(T,k)." The lag parameter is chosen according to the Akaike information criterion and to eliminate serial correlation in residuals. The trace statistics with significance at the $10 \%$ and $5 \%$ levels indicated by $* *$ and * are presented (Cheung and Lai, 1993). The maximum eigenvalue statistics give similar results. Significant cointegrating vectors are presented in the "CV(s)" column. The cointegrating vectors are normalized such that the coefficient of the export variable is unity. 
Table 3a. The Basic Export Demand Specification

\begin{tabular}{|c|c|c|c|}
\hline \multirow[b]{2}{*}{ Variables } & \multicolumn{3}{|c|}{ Aggregate } \\
\hline & DY & RY & TY \\
\hline Constant & $\begin{array}{l}3.8344^{*} \\
(3.231)\end{array}$ & $\begin{array}{l}0.9884 * \\
(2.977)\end{array}$ & $\begin{array}{l}1.2342 * \\
(2.772)\end{array}$ \\
\hline $\mathrm{Y}_{t-1}$ & $\begin{array}{c}-0.4869 * \\
(-5.350)\end{array}$ & $\begin{array}{c}-0.8113^{*} \\
(-5.205)\end{array}$ & $\begin{array}{c}-0.7779 * \\
(-5.487)\end{array}$ \\
\hline$Y_{t-2}$ & $\begin{array}{c}-0.2383 * \\
(-3.892)\end{array}$ & $\begin{array}{c}-0.7189 * \\
(-3.983)\end{array}$ & $\begin{array}{c}-0.6869 * \\
(-4.040)\end{array}$ \\
\hline $\mathrm{Y}_{t-3}$ & & $\begin{array}{c}-0.5072 * \\
(-3.375)\end{array}$ & $\begin{array}{c}-0.4812^{*} \\
(-3.284)\end{array}$ \\
\hline $\mathrm{Y}_{t-4}$ & & $\begin{array}{c}-0.2459 * \\
(-1.993)\end{array}$ & $\begin{array}{c}-0.2383^{\wedge} \\
(-1.910)\end{array}$ \\
\hline$Y_{t-5}$ & & $\begin{array}{l}-0.1145 \\
(-1.472)\end{array}$ & $\begin{array}{l}-0.1139 \\
(-1.435)\end{array}$ \\
\hline $\mathrm{X}_{t-3}$ & & $\begin{array}{l}1.3044^{*} \\
(2.003)\end{array}$ & $\begin{array}{l}1.2475^{\wedge} \\
(1.919)\end{array}$ \\
\hline$X_{t-5}$ & $\begin{array}{l}2.8806^{*} \\
(3.443)\end{array}$ & $\begin{array}{l}2.0906^{*} \\
(2.392)\end{array}$ & $\begin{array}{l}2.2093 * \\
(2.577)\end{array}$ \\
\hline $\mathrm{X}_{t-6}$ & $\begin{array}{l}2.1536^{*} \\
(2.675)\end{array}$ & $\begin{array}{l}1.3220^{*} \\
(2.196)\end{array}$ & $\begin{array}{l}1.4543^{*} \\
(2.423)\end{array}$ \\
\hline $\mathrm{E}_{t-1}$ & $\begin{array}{c}-0.2661 * \\
(-3.242)\end{array}$ & $\begin{array}{c}-0.1816^{*} \\
(-2.973)\end{array}$ & $\begin{array}{c}-0.2112 * \\
(-2.774)\end{array}$ \\
\hline $\bar{R}^{2}$ & 0.4711 & 0.5477 & 0.5516 \\
\hline $\mathrm{Q}(4)$ & $\begin{array}{c}2.4642 \\
{[0.651]}\end{array}$ & $\begin{array}{c}0.3247 \\
{[0.988]}\end{array}$ & $\begin{array}{c}0.4924 \\
{[0.974]}\end{array}$ \\
\hline $\mathrm{Q}(8)$ & $\begin{array}{l}3.2292 \\
{[0.919]}\end{array}$ & $\begin{array}{l}5.1223 \\
{[0.744]}\end{array}$ & $\begin{array}{l}4.4241 \\
{[0.817]}\end{array}$ \\
\hline $\mathrm{Q}(12)$ & $\begin{array}{l}5.5250 \\
{[0.938]}\end{array}$ & $\begin{array}{c}6.5870 \\
{[0.884]}\end{array}$ & $\begin{array}{l}5.4246 \\
{[0.942]}\end{array}$ \\
\hline
\end{tabular}


Table 3b. The Basic Export Demand Specification

\begin{tabular}{|c|c|c|c|c|c|c|}
\hline \multirow[b]{2}{*}{ Variables } & \multicolumn{3}{|c|}{ Japan } & \multicolumn{3}{|c|}{ The U.S. } \\
\hline & DY & RY & TY & DY & RY & TY \\
\hline Constant & $\begin{array}{c}-0.0201 * \\
(-2.359)\end{array}$ & $\begin{array}{c}-1.4590^{*} \\
(-4.795)\end{array}$ & $\begin{array}{c}-1.9488 * \\
(-4.985)\end{array}$ & $\begin{array}{l}2.0638 * \\
(3.807)\end{array}$ & $\begin{array}{c}-0.2323 * \\
(-2.438)\end{array}$ & $\begin{array}{c}-0.1034^{*} \\
(-2.420)\end{array}$ \\
\hline $\mathrm{Y}_{t-1}$ & $\begin{array}{c}-0.7129 * \\
(-5.828)\end{array}$ & $\begin{array}{c}-0.7344^{*} \\
(-9.101)\end{array}$ & $\begin{array}{c}-0.7395 * \\
(-7.822)\end{array}$ & $\begin{array}{c}-0.4124 * \\
(-4.524)\end{array}$ & $\begin{array}{c}-0.6886^{*} \\
(-6.106)\end{array}$ & $\begin{array}{c}-0.6932 * \\
(-6.641)\end{array}$ \\
\hline$Y_{t-2}$ & $\begin{array}{c}-0.3393 * \\
(-2.383)\end{array}$ & $\begin{array}{c}-0.5361^{*} \\
(-4.598)\end{array}$ & $\begin{array}{c}-0.5331 * \\
(-4.412)\end{array}$ & $\begin{array}{c}-0.1356^{\wedge} \\
(-1.741)\end{array}$ & $\begin{array}{c}-0.4706^{*} \\
(-4.141)\end{array}$ & $\begin{array}{c}-0.5293 * \\
(-4.381)\end{array}$ \\
\hline $\mathrm{Y}_{t-3}$ & $\begin{array}{l}-0.1632 \\
(-1.307)\end{array}$ & $\begin{array}{c}-0.3660 * \\
(-3.515)\end{array}$ & $\begin{array}{c}-0.4269 * \\
(-3.661)\end{array}$ & & $\begin{array}{c}-0.2260 * \\
(-2.277)\end{array}$ & $\begin{array}{c}-0.2863^{*} \\
(-2.672)\end{array}$ \\
\hline$Y_{t-4}$ & $\begin{array}{c}-0.2422^{*} \\
(-2.366)\end{array}$ & $\begin{array}{c}-0.1466^{\wedge} \\
(-1.928)\end{array}$ & $\begin{array}{c}-0.2398 * \\
(-2.319)\end{array}$ & & $\begin{array}{l}-0.1108 \\
(-1.216)\end{array}$ & $\begin{array}{l}-0.1101 \\
(-1.326)\end{array}$ \\
\hline$Y_{t-5}$ & & & $\begin{array}{l}-0.1170 \\
(-1.615)\end{array}$ & & & \\
\hline$Y_{t-6}$ & & $\begin{array}{l}0.1115^{*} \\
(2.314)\end{array}$ & & & & \\
\hline$Y_{t-9}$ & & $\begin{array}{c}0.0973 \\
(1.328)\end{array}$ & $\begin{array}{l}0.1384^{\wedge} \\
(1.755)\end{array}$ & & & \\
\hline $\mathrm{X}_{t-1}$ & $\begin{array}{c}0.7114 \\
(1.479)\end{array}$ & $\begin{array}{l}0.4066^{\wedge} \\
(1.822)\end{array}$ & $\begin{array}{l}0.4399 * \\
(2.062)\end{array}$ & & & \\
\hline $\mathrm{X}_{t-2}$ & & & & & $\begin{array}{l}2.9201 * \\
(2.353)\end{array}$ & $\begin{array}{l}2.4186^{\wedge} \\
(1.939)\end{array}$ \\
\hline $\mathrm{X}_{t-3}$ & $\begin{array}{l}0.8252^{\wedge} \\
(1.681)\end{array}$ & $\begin{array}{l}0.5435^{*} \\
(2.101)\end{array}$ & $\begin{array}{l}0.5519 * \\
(2.014)\end{array}$ & & $\begin{array}{l}2.5072^{\wedge} \\
(1.767)\end{array}$ & $\begin{array}{l}2.5085^{*} \\
(2.292)\end{array}$ \\
\hline $\mathrm{X}_{t-5}$ & & & & $\begin{array}{l}3.3342^{*} \\
(2.344)\end{array}$ & $\begin{array}{l}2.9915 * \\
(2.049)\end{array}$ & $\begin{array}{l}3.2350 * \\
(2.344)\end{array}$ \\
\hline $\mathrm{X}_{t-8}$ & & & & $\begin{array}{l}3.1869^{\wedge} \\
(1.791)\end{array}$ & & \\
\hline $\mathrm{R}_{t-4}$ & $\begin{array}{c}0.4198 \\
(1.585)\end{array}$ & & & & $\begin{array}{c}1.3851 \\
(1.387)\end{array}$ & \\
\hline $\mathrm{E} 1_{t-1}$ & & $\begin{array}{c}-0.0909 * \\
(-4.823)\end{array}$ & $\begin{array}{c}-0.1053 * \\
(-5.002)\end{array}$ & $\begin{array}{c}-0.2047 * \\
(-2.822)\end{array}$ & $\begin{array}{c}-0.1403 * \\
(-2.368)\end{array}$ & $\begin{array}{c}-0.1764 * \\
(-2.378)\end{array}$ \\
\hline $\mathrm{E} 2_{t-1}$ & & & & $\begin{array}{c}-0.1259 * \\
(-2.229)\end{array}$ & & \\
\hline $\bar{R}^{2}$ & 0.3740 & 0.4718 & 0.4759 & 0.3976 & 0.4384 & 0.4874 \\
\hline $\mathrm{Q}(4)$ & $\begin{array}{c}0.4651 \\
{[0.977]}\end{array}$ & $\begin{array}{c}0.6142 \\
{[0.961]}\end{array}$ & $\begin{array}{c}0.7386 \\
{[0.946]}\end{array}$ & $\begin{array}{c}1.5631 \\
{[0.815]}\end{array}$ & $\begin{array}{c}3.6114 \\
{[0.461]}\end{array}$ & $\begin{array}{l}5.0539 \\
{[0.282]}\end{array}$ \\
\hline
\end{tabular}




\begin{tabular}{lcccccc}
\hline & & Japan & & \multicolumn{3}{c}{ The U.S. } \\
Variables & DY & RY & TY & DY & RY & TY \\
\hline \multirow{2}{*}{ Q(8) } & 2.6731 & 2.9509 & 5.0247 & 2.2447 & 4.6809 & 5.3222 \\
& {$[0.953]$} & {$[0.937]$} & {$[0.755]$} & {$[0.973]$} & {$[0.791]$} & {$[0.723]$} \\
\multirow{2}{*}{$(12)$} & 5.5622 & 7.1492 & 10.1518 & 9.9818 & 7.9078 & 9.0731 \\
& {$[0.937]$} & {$[0.848]$} & {$[0.603]$} & {$[0.618]$} & {$[0.792]$} & {$[0.697]$} \\
\hline
\end{tabular}

Note: The table contains results from estimating

$$
\mathrm{Y}_{\mathrm{i}, \mathrm{j}, \mathrm{t}}=\alpha+\sum_{\mathrm{k}=1}^{\mathrm{n}} \alpha_{\mathrm{i}, \mathrm{j}, \mathrm{k}} \mathrm{Y}_{\mathrm{i}, \mathrm{j}, \mathrm{t}-\mathrm{k}}+\sum_{\mathrm{k}=1}^{\mathrm{m}} \beta_{\mathrm{i}, \mathrm{j}, \mathrm{k}} \mathrm{X}_{\mathrm{j}, \mathrm{t}-\mathrm{k}}+\sum_{\mathrm{k}=1}^{\mathrm{p}} \gamma_{\mathrm{i}, \mathrm{j}, \mathrm{k}} \mathrm{R}_{\mathrm{i}, \mathrm{j}, \mathrm{t}-\mathrm{k}}+\theta_{\mathrm{ij}} \mathrm{E}_{\mathrm{i}, \mathrm{j}, \mathrm{t}-1}+\varepsilon_{\mathrm{i}, \mathrm{j}, \mathrm{t}},
$$

where $\mathrm{Y}, \mathrm{X}$, and $\mathrm{R}$ are, respectively, the first log differences of Hong Kong exports, foreign income, and type-and-destination specific real exchange rates. E1 and E2 are error correction terms. The $\mathrm{i}$-subscript indicates the export types and $\mathrm{i}=$ domestic exports, re-exports, and total exports. The export destinations are given by the $j$-subscript and $j=$ aggregate, Japan, and the US. Table 3a contains results for aggregate export data and Table $3 b$ contains results for exports to Japan and the US. In the Table, DY = domestic exports, RY = re-exports, and TY = total exports. Robust $t$-statistics are given in parentheses underneath the coefficient estimates. Significance at the $5 \%(10 \%)$ level is indicated by $*^{\wedge}\left({ }^{\wedge}\right.$. For brevity, only significant estimates are presented. $\mathrm{Q}(k)$ gives the Ljung-Box statistic constructed from the first $k$ autocorrelation coefficients. The brackets below the $\mathrm{Q}(k)$ statistics contain their $p$-values. 
Table 4a. The Augmented Export Demand Specification

\begin{tabular}{|c|c|c|c|}
\hline \multirow[b]{2}{*}{ Variables } & \multicolumn{3}{|c|}{ Aggregate } \\
\hline & DY & RY & TY \\
\hline Constant & $\begin{array}{l}3.6256^{*} \\
(3.178)\end{array}$ & $\begin{array}{l}0.9986^{*} \\
(4.244)\end{array}$ & $\begin{array}{l}1.2716^{*} \\
(4.053)\end{array}$ \\
\hline $\mathrm{Y}_{t-1}$ & $\begin{array}{c}-0.5426^{*} \\
(-6.629)\end{array}$ & $\begin{array}{c}-0.7696^{*} \\
(-8.001)\end{array}$ & $\begin{array}{c}-0.7744 * \\
(-7.695)\end{array}$ \\
\hline$Y_{t-2}$ & $\begin{array}{c}-0.3060 * \\
(-5.138)\end{array}$ & $\begin{array}{c}-0.6590^{*} \\
(-5.364)\end{array}$ & $\begin{array}{c}-0.6787^{*} \\
(-4.929)\end{array}$ \\
\hline $\mathrm{Y}_{t-3}$ & & $\begin{array}{c}-0.4020^{*} \\
(-3.506)\end{array}$ & $\begin{array}{c}-0.4077 * \\
(-3.043)\end{array}$ \\
\hline $\mathrm{Y}_{t-4}$ & & $\begin{array}{c}-0.1882^{\wedge} \\
(-1.849)\end{array}$ & $\begin{array}{l}-0.1681 \\
(-1.622)\end{array}$ \\
\hline$Y_{t-5}$ & & $\begin{array}{c}-0.1068^{\wedge} \\
(-1.780)\end{array}$ & $\begin{array}{l}-0.0949 \\
(-1.475)\end{array}$ \\
\hline $\mathrm{X}_{t-3}$ & & $\begin{array}{l}1.4926^{*} \\
(2.894)\end{array}$ & $\begin{array}{l}1.3848^{*} \\
(2.749)\end{array}$ \\
\hline $\mathrm{X}_{t-5}$ & $\begin{array}{l}3.2691^{*} \\
(4.297)\end{array}$ & $\begin{array}{l}2.2720^{*} \\
(3.036)\end{array}$ & $\begin{array}{l}2.5829^{*} \\
(3.458)\end{array}$ \\
\hline$X_{t-6}$ & $\begin{array}{l}2.5372 * \\
(3.294)\end{array}$ & $\begin{array}{l}1.4069^{*} \\
(2.338)\end{array}$ & $\begin{array}{l}1.7299^{*} \\
(2.683)\end{array}$ \\
\hline $\mathrm{E}_{t-1}$ & $\begin{array}{c}-0.2490^{*} \\
(-3.150)\end{array}$ & $\begin{array}{c}-0.1802 * \\
(-4.209)\end{array}$ & $\begin{array}{c}-0.2149^{*} \\
(-4.005)\end{array}$ \\
\hline $\mathrm{V}_{t-1}$ & $\begin{array}{c}-235.384^{\wedge} \\
(-1.776)\end{array}$ & $\begin{array}{c}-104.963 * \\
(-2.263)\end{array}$ & $\begin{array}{c}-116.228^{*} \\
(-2.042)\end{array}$ \\
\hline $\mathrm{R}_{t-1}^{*}$ & $\begin{array}{c}-1.0796^{*} \\
(-2.067)\end{array}$ & $\begin{array}{l}-0.8659 \\
(-1.453)\end{array}$ & $\begin{array}{c}-1.0127^{\wedge} \\
(-1.780)\end{array}$ \\
\hline $\mathrm{W}_{t-1}$ & $\begin{array}{c}-2.0734^{*} \\
(-2.346)\end{array}$ & $\begin{array}{c}-2.2348^{*} \\
(-2.353)\end{array}$ & $\begin{array}{c}-1.9365^{*} \\
(-2.090)\end{array}$ \\
\hline $\mathrm{W}_{t-5}$ & $\begin{array}{l}1.6705^{*} \\
(2.134)\end{array}$ & & $\begin{array}{c}1.0848 \\
(1.370)\end{array}$ \\
\hline $\mathrm{CN}_{t-2}$ & $\begin{array}{l}-0.8816 \\
(-1.602)\end{array}$ & $\begin{array}{c}-1.3911^{*} \\
(-2.324)\end{array}$ & $\begin{array}{c}-1.2202^{*} \\
(-2.085)\end{array}$ \\
\hline $\bar{R}^{2}$ & 0.5896 & 0.6316 & 0.6506 \\
\hline $\mathrm{Q}(4)$ & $\begin{array}{c}0.5992 \\
{[0.963]}\end{array}$ & $\begin{array}{c}0.6148 \\
{[0.961]}\end{array}$ & $\begin{array}{c}0.9742 \\
{[0.914]}\end{array}$ \\
\hline $\mathrm{Q}(8)$ & $\begin{array}{c}1.2907 \\
{[0.996]}\end{array}$ & $\begin{array}{l}9.3425 \\
{[0.314]}\end{array}$ & $\begin{array}{l}9.3463 \\
{[0.314]}\end{array}$ \\
\hline $\mathrm{Q}(12)$ & $\begin{array}{l}2.3919 \\
{[0.999]}\end{array}$ & $\begin{array}{l}15.4257 \\
{[0.219]}\end{array}$ & $\begin{array}{l}12.9779 \\
{[0.371]}\end{array}$ \\
\hline
\end{tabular}


Table 4b. The Augmented Export Demand Specification

\begin{tabular}{|c|c|c|c|c|c|c|}
\hline \multirow[b]{2}{*}{ Variables } & \multicolumn{3}{|c|}{ Japan } & \multicolumn{3}{|c|}{ The U.S. } \\
\hline & DY & RY & TY & DY & RY & TY \\
\hline Constant & $\begin{array}{l}-0.0109 \\
(-1.077)\end{array}$ & $\begin{array}{c}-1.4182 * \\
(-4.792)\end{array}$ & $\begin{array}{c}-1.6986^{*} \\
(-4.712)\end{array}$ & $\begin{array}{l}0.7363^{\wedge} \\
(1.887)\end{array}$ & $\begin{array}{c}-0.2731 * \\
(-3.318)\end{array}$ & $\begin{array}{c}-0.0932 * \\
(-2.406)\end{array}$ \\
\hline$Y_{t-1}$ & $\begin{array}{c}-0.7119 * \\
(-6.335)\end{array}$ & $\begin{array}{c}-0.7858 * \\
(-9.958)\end{array}$ & $\begin{array}{c}-0.7302 * \\
(-8.101)\end{array}$ & $\begin{array}{c}-0.6091 * \\
(-8.301)\end{array}$ & $\begin{array}{c}-0.6836^{*} \\
(-7.840)\end{array}$ & $\begin{array}{c}-0.7067 * \\
(-8.852)\end{array}$ \\
\hline$Y_{t-2}$ & $\begin{array}{c}-0.2815^{*} \\
(-2.308)\end{array}$ & $\begin{array}{c}-0.5886^{*} \\
(-5.680)\end{array}$ & $\begin{array}{c}-0.4977 * \\
(-4.425)\end{array}$ & $\begin{array}{c}-0.2505^{*} \\
(-3.099)\end{array}$ & $\begin{array}{c}-0.4508 * \\
(-4.685)\end{array}$ & $\begin{array}{c}-0.5330 * \\
(-5.441)\end{array}$ \\
\hline$Y_{t-3}$ & & $\begin{array}{c}-0.3982 * \\
(-3.800)\end{array}$ & $\begin{array}{c}-0.3311 * \\
(-3.123)\end{array}$ & & $\begin{array}{c}-0.2108^{*} \\
(-2.192)\end{array}$ & $\begin{array}{c}-0.2662 * \\
(-2.668)\end{array}$ \\
\hline $\mathrm{Y}_{t-4}$ & $\begin{array}{c}-0.1483^{\wedge} \\
(-1.768)\end{array}$ & $\begin{array}{c}-0.1501 * \\
(-2.011)\end{array}$ & $\begin{array}{l}-0.1277 \\
(-1.486)\end{array}$ & & $\begin{array}{l}-0.1412 \\
(-1.650)\end{array}$ & $\begin{array}{l}-0.1302 \\
(-1.586)\end{array}$ \\
\hline$Y_{t-6}$ & & $\begin{array}{l}0.1453 * \\
(2.987)\end{array}$ & & & & \\
\hline$Y_{t-9}$ & & $\begin{array}{c}0.0759 \\
(1.191)\end{array}$ & $\begin{array}{l}0.1439 * \\
(2.023)\end{array}$ & & & \\
\hline $\mathrm{X}_{t-1}$ & & $\begin{array}{l}0.4134^{\wedge} \\
(1.954)\end{array}$ & $\begin{array}{l}0.3899^{\wedge} \\
(1.835)\end{array}$ & & & \\
\hline $\mathrm{X}_{t-2}$ & & & & & $\begin{array}{l}3.0964 * \\
(2.729)\end{array}$ & $\begin{array}{l}3.1131 * \\
(2.675)\end{array}$ \\
\hline $\mathrm{X}_{t-3}$ & & $\begin{array}{l}0.4569^{\wedge} \\
(1.907)\end{array}$ & $\begin{array}{l}0.5338 * \\
(1.992)\end{array}$ & & $\begin{array}{l}2.7913 * \\
(2.004)\end{array}$ & $\begin{array}{l}2.5140 * \\
(2.571)\end{array}$ \\
\hline$X_{t-5}$ & & & & $\begin{array}{l}3.1519 * \\
(2.454)\end{array}$ & $\begin{array}{l}2.5617^{\wedge} \\
(1.910)\end{array}$ & $\begin{array}{l}2.3907^{\wedge} \\
(1.977)\end{array}$ \\
\hline $\mathrm{X}_{t-8}$ & & & & $\begin{array}{l}3.5946^{*} \\
(2.112)\end{array}$ & & \\
\hline $\mathrm{E}_{t-1}$ & & $\begin{array}{c}-0.0878 * \\
(-4.820)\end{array}$ & $\begin{array}{c}-0.0919 * \\
(-4.746)\end{array}$ & $\begin{array}{c}-0.1496 * \\
(-2.084)\end{array}$ & $\begin{array}{c}-0.1599 * \\
(-3.275)\end{array}$ & $\begin{array}{c}-0.1681 * \\
(-2.556)\end{array}$ \\
\hline $\mathrm{V}_{t-2}$ & & $\begin{array}{c}18.4074^{*} \\
(2.254)\end{array}$ & & & & \\
\hline $\mathrm{V}_{t-4}$ & & & & $\begin{array}{c}1055.09 * \\
(2.452)\end{array}$ & $\begin{array}{c}840.324^{*} \\
(2.318)\end{array}$ & \\
\hline $\mathrm{V}_{t-8}$ & & & & $\begin{array}{c}913.320 * \\
(2.358)\end{array}$ & & \\
\hline $\mathrm{R}_{t-2}^{*}$ & & $\begin{array}{c}0.3370 \\
(1.522)\end{array}$ & & & & \\
\hline
\end{tabular}




\begin{tabular}{lcccccc}
\hline & \multicolumn{3}{c}{ Japan } & & \multicolumn{3}{c}{ The U.S. } \\
Variables & $\mathbf{D Y}$ & $\mathbf{R Y}$ & $\mathbf{T Y}$ & $\mathbf{D Y}$ & $\mathbf{R Y}$ & $\mathbf{T Y}$ \\
\hline $\mathrm{R}_{t-4}^{*}$ & $0.7956^{*}$ & & & & $1.5854^{*}$ & $1.4052^{*}$ \\
& $(2.087)$ & & & & $(2.596)$ & $(2.437)$ \\
$\mathrm{W}_{t-1}$ & $-2.7300^{\wedge}$ & & $-1.3794^{\wedge}$ & $-2.1625^{*}$ & $-1.9366^{*}$ & $-2.0913^{*}$ \\
& $(-1.691)$ & & $(-1.944)$ & $(-3.583)$ & $(-2.073)$ & $(-2.731)$ \\
$\mathrm{W}_{t-2}$ & & $-1.4199^{*}$ & & & & \\
& & $(-2.017)$ & & & & \\
$\mathrm{W}_{t-9}$ & & & & $-1.9399^{*}$ & & \\
& & & & $(-2.786)$ & & \\
$\mathrm{CN}_{t-2}$ & & & & -0.9850 & & \\
& & & & $(-1.420)$ & & \\
$\bar{R}^{2}$ & 0.3791 & 0.5037 & 0.4902 & 0.4618 & 0.5063 & 0.5493 \\
$\mathrm{Q}(4)$ & 0.8397 & 1.6279 & 1.7638 & 2.7325 & 5.2459 & 6.1479 \\
& {$[0.933]$} & {$[0.804]$} & {$[0.779]$} & {$[0.604]$} & {$[0.263]$} & {$[0.188]$} \\
$\mathrm{Q}(8)$ & 3.5808 & 4.6780 & 6.6638 & 3.7525 & 10.2446 & 7.6891 \\
& {$[0.893]$} & {$[0.791]$} & {$[0.573]$} & {$[0.879]$} & {$[0.248]$} & {$[0.464]$} \\
$\mathrm{Q}(12)$ & 7.2349 & 8.5714 & 10.7899 & 7.0219 & 13.8514 & 12.9129 \\
& {$[0.842]$} & {$[0.739]$} & {$[0.547]$} & {$[0.856]$} & {$[0.310]$} & {$[0.375]$} \\
\hline
\end{tabular}

Note: The table contains results from estimating

$$
\begin{aligned}
\mathrm{Y}_{\mathrm{i}, \mathrm{j}, \mathrm{t}}= & \alpha+\sum_{\mathrm{k}=1}^{\mathrm{n}} \alpha_{\mathrm{i}, \mathrm{j}, \mathrm{k}} \mathrm{Y}_{\mathrm{i}, \mathrm{j}, \mathrm{t}-\mathrm{k}}+\sum_{\mathrm{k}=1}^{\mathrm{m}} \beta_{\mathrm{i}, \mathrm{j}, \mathrm{k}} \mathrm{X}_{\mathrm{j}, \mathrm{t}-\mathrm{k}}+\sum_{\mathrm{k}=1}^{\mathrm{p}} \gamma_{\mathrm{i}, \mathrm{j}, \mathrm{k}} \mathrm{R}_{\mathrm{i}, \mathrm{j}, \mathrm{t}-\mathrm{k}}+\theta_{\mathrm{ij}} \mathrm{E}_{\mathrm{i}, \mathrm{j}, \mathrm{t}-1}+ \\
& \sum_{\mathrm{k}=0}^{\mathrm{q}} \delta_{\mathrm{i}, \mathrm{j}, \mathrm{k}} \mathrm{V}_{\mathrm{i}, \mathrm{j}, \mathrm{t}, \mathrm{k}}+\sum_{\mathrm{k}=1}^{\mathrm{s}} \gamma_{\mathrm{i}, \mathrm{j}, \mathrm{k}}^{*} \mathrm{R}_{\mathrm{i}, \mathrm{j}, \mathrm{t}-\mathrm{k}}^{*}+\sum_{\mathrm{k}=1}^{\mathrm{r}} \lambda_{\mathrm{k}} \mathrm{W}_{\mathrm{t}-\mathrm{k}}+\sum_{\mathrm{k}=1}^{\mathrm{u}} \tau_{\mathrm{i}, \mathrm{j}, \mathrm{k}} \mathrm{CN}_{\mathrm{i}, \mathrm{j}, \mathrm{t}-\mathrm{k}}+\varepsilon_{\mathrm{i}, \mathrm{j}, \mathrm{t}},
\end{aligned}
$$

where $\mathrm{V}$ is the real exchange rate volatility given by GARCH estimates, $\mathrm{R}^{*}$ is the "third" country price variable based on the Hong Kong export UVI and the destination economy's overall import UVI, $\mathrm{W}$ is the first log difference of the real payroll index, and $\mathrm{CN}$ is the first log difference of the UVI of Hong Kong imports from China relative to the type-and-destination-specific UVI of Hong Kong exports. See the Notes to Table 3 for definitions of other variables. Table 4 a contains results for aggregate export data and Table $4 \mathrm{~b}$ contains results for exports to Japan and the US. 
Table 5. The Adjusted $\mathbf{R}^{2}$

A. Basic Specification

\begin{tabular}{lcccc}
\hline \multirow{2}{*}{$\begin{array}{c}\text { Export } \\
\text { Category }\end{array}$} & Ys & Xs, Rs & Ys, E & All \\
\hline DYA & 0.3676 & 0.0445 & 0.3930 & 0.4711 \\
RYA & 0.4245 & 0.0610 & 0.4883 & 0.5477 \\
TYA & 0.4385 & 0.0643 & 0.4851 & 0.5516 \\
DYJP & 0.3560 & 0.0019 & 0.3560 & 0.3740 \\
RYJP & 0.2711 & 0.0756 & 0.4381 & 0.4718 \\
TYJP & 0.2740 & 0.0701 & 0.4380 & 0.4759 \\
DYUS & 0.3040 & 0.0373 & 0.3423 & 0.3976 \\
RYUS & 0.3358 & 0.0317 & 0.3387 & 0.4384 \\
TYUS & 0.4027 & 0.0150 & 0.4010 & 0.4874 \\
\hline
\end{tabular}

B. Final Specification

\begin{tabular}{lccccc}
\hline \multirow{2}{*}{$\begin{array}{l}\text { Export } \\
\text { Category }\end{array}$} & Ys & Xs & Ys, E & Vs, R* s, Ws, CNs & All \\
\hline DYA & 0.3676 & 0.0445 & 0.3930 & 0.0420 & 0.5896 \\
RYA & 0.4245 & 0.0610 & 0.4883 & 0.0775 & 0.6316 \\
TYA & 0.4385 & 0.0643 & 0.4851 & 0.0867 & 0.6506 \\
DYJP & 0.3547 & --- & 0.3547 & -0.0039 & 0.3791 \\
RYJP & 0.2711 & 0.0756 & 0.4381 & 0.0243 & 0.5037 \\
TYJP & 0.2783 & 0.0701 & 0.4313 & 0.0187 & 0.4902 \\
DYUS & 0.3040 & 0.0373 & 0.3109 & 0.0123 & 0.4618 \\
RYUS & 0.3358 & 0.0098 & 0.3387 & 0.0550 & 0.5063 \\
TYUS & 0.4027 & 0.0150 & 0.4010 & 0.0439 & 0.5493 \\
\hline
\end{tabular}

Note: The table contains the adjusted $\mathrm{R}^{2}$ statistics from fitting individual groups of regressors to the export demand equations. Panel A presents the results based on the basic export demand specification (equation (2)) reported in Table 3. Panel B presents the results based on the export demand specification (equation (3)) reported in Table 4 . The adjusted $\mathrm{R}^{2} \mathrm{~s}$ reported under "All" are the statistics when all the regressors are included. The export categories are defined by the combination of export types and export destinations. $\mathrm{DY}=$ domestic exports, $\mathrm{RY}=$ re-exports, $\mathrm{TY}=$ total exports, $\mathrm{A}=$ aggregate exports, $\mathrm{JP}=$ exports to Japan, and US $=$ exports to the US. See the previous tables for definitions of other variables. 
Figure 1. Hong Kong Aggregate Exports, Quantum Indexes

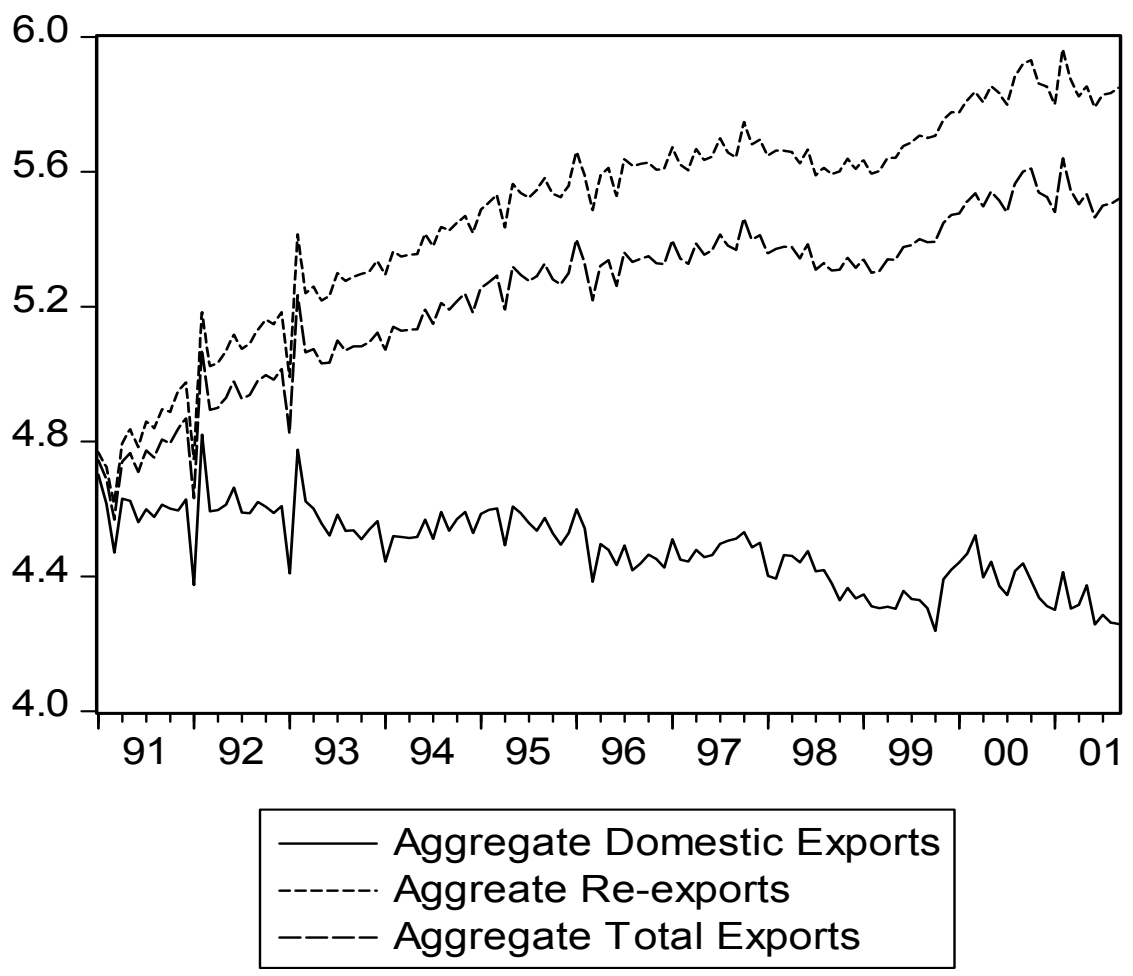

\section{Figure 2. Hong Kong Real Effective Exchange Rates}

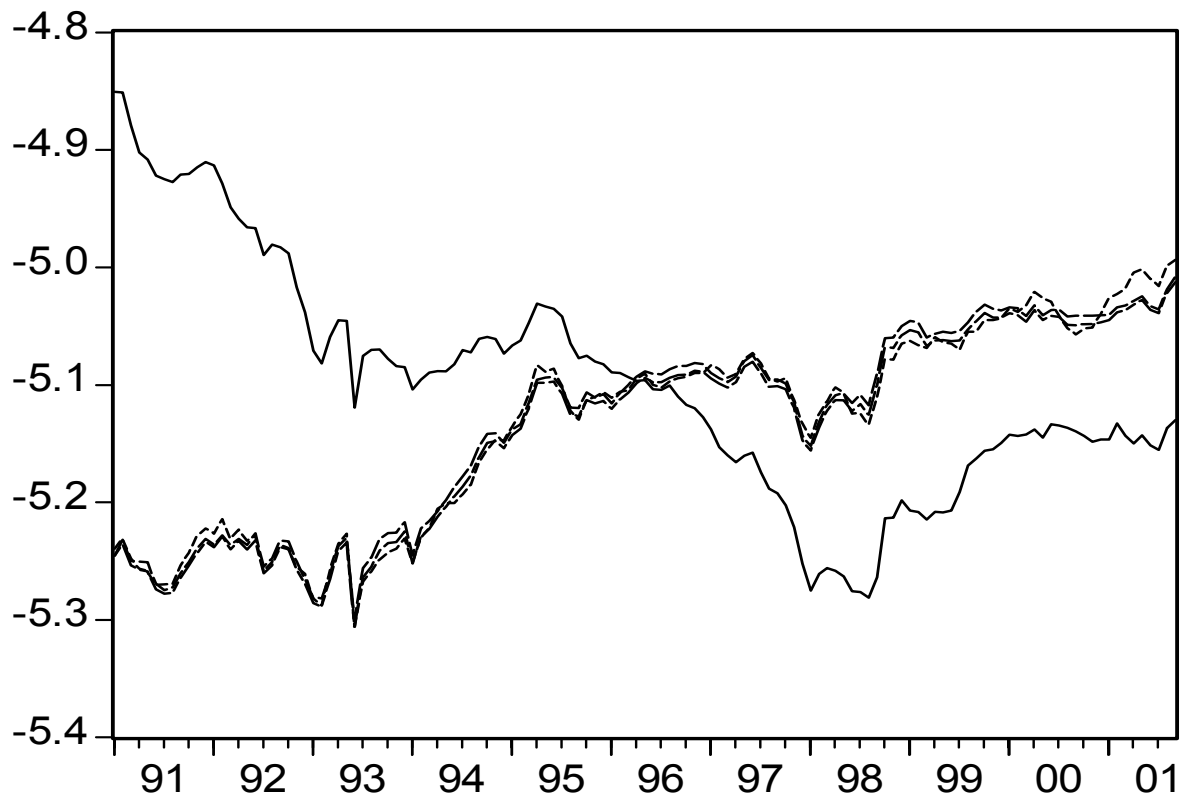

- Real Effective Exchange Rate Based on the Hong Kong CPI Index

------- Real Effective Exchange Rate Based on the UVI of Aggregate Domestic Exports

- - - Real Effective Exchange Rate Based on the UVI of Aggregate Re-exports

---- Real Effective Exchange Rate Based on the UVI of Aggregate Total Exports 
